\title{
The Nigerian State, Security Management Mandate and Challenges in the Niger-Delta Region, Nigeria.
}

\author{
Ufot Akpan Phenson (Ph.D) in view ${ }^{1}$, Peter Ojie (Ph.D) in view. , \\ ${ }^{2}$ John O. Esin (Ph.D) ${ }^{3}$ \\ ${ }^{I}$ Department of Political Science \& Public Administration, University of Uyo, Uyo, Akwa Ibom State, Nigeria. \\ ${ }^{2}$ Department of Political Science \& Public Administration, University of Uyo, Uyo, Akwa Ibom State, Nigeria. \\ ${ }^{3}$ Department of Geography/Natural Resources Management, University of Uyo, Uyo, Akwa Ibom State, Nigeria.
}

\begin{abstract}
All over the world, provision of security to guaranty the protection of lives and property, welfare and rights of the citizenry has been the statutory responsibility of a responsible government. This is in view of the fact that individuals under social contract have surrendered their sovereignty to government, while government undertakes the protection of lives and property. Therefore, any government that cannot protect lives and property, guaranty civil liberties and public good is simply unattainable in today's realities. It is this legitimacy that mandates the Nigerian state (government) to maintain law and order, enforce rules and regulation of human conduct, and provides essential services to the citizenry. The 1999 constitution of the Federal Republic of Nigeria also authorizes the National Assembly to make laws regarding the maintenance and security of public safety and order. However, the Nigerian state seems to havebeen insensitive to security matters.The attendant effect being increased violence, terrorism and insurgency as well as high profile crimes which pose threats to national security especially, in the Niger-Delta region of Nigeria.This paper examines the effectiveness or otherwise of the Nigerian state in the discharge of its statutory security management mandate of protecting lives and property in Nigeria. It adopts descriptive method while social contract is the theoretical framework. Data collected centers on both primary and secondary sources. It was uncovered that government officials/political office holders who are entrusted with the responsibility of managing security to ensure protection of lives and property and the well-being of the citizenry were insensitive to the security plight of the citizenry. This has resulted in incessant and uncontrollable break-down of law and order leading to loss of lives and property in recent times. Based on these, it is recommended among other things that, Nigerian government at all levels should fund, equip, train and re-train security operatives to make them cope with the myriad of security challenges in the Niger-Delta region and the nation at large since security is the bed-rock of economic development.
\end{abstract}

Key Words: Nigerian State, Security Management Mandate, Niger-Delta Region, Security challenges.

\section{Introduction:}

The Nigerian state refers to the government of the Federal Republic of Nigeria. It is an independent, legal and sovereign entity with authority to execute certain statutory and constitutional obligations to Nigerian citizens. The Nigerian state comprises thirty-six states with a federal capital territory in Abuja. It runs a federal structure of three tiers of government (federal, state and local governments). Its government also operates three arms of government, namely; executive, legislative and judiciary under a presidential system of government. The Nigerian Constitution of 1999 spelt out statutory responsibilities of the governmentwhich includes the mandate to manage security challenges on behalf of her citizens, amongst other functions that border on peaceful co-existence of the federating units that make up the Nigerian state. The Nigerian State is currently faced with numerous challenges that range from oil-related issues, environmental, ethnic, political, economic, social, religious, cultural and criminal issues which pose serious threats to her unity and security. Most of these challenges arise from the oil-dependent economy with its attendant oil-related security and environmental challenges that has made the Niger-Delta region a hot bed of insecurities and contradictions. The issue of security has become a contention for the Nigerian state, her oil industry and the oil-bearing Niger-Delta region.

However, the Nigerian state since independence in 1960 has gone through several military coups, civil war between 1967-1970, despotic military regimes with very few civilian administrations. Therefore, to provide for corporate unity and security for her citizens is one of the statutory and constitutional responsibilities of the Nigerian state. These divergent security challenges are to be examined by this work with a view to recommending ways of ameliorating these challenges since security is important on its own merit as a prerequisite for developments in any society.

There are negative effects of oil operations to the host communities and their environment, high unemployment rates and accompanying poverty that is prevalent in these oil-bearingcommunities, which presents a paradox of poverty in the midst of oil wealth. It is rather very grievous to the Niger-Deltans.These 
grievances have continued to generate mass protests and violent agitations from the indigenes of the NigerDelta. However, these protests led the Nigerian state to respond with a militarization policy that involved stationing occupation military forces meant to check the continuing protests from the region.

However, the militarization policy as government action seems to have exacerbated security situations in the region as the wanton killings by the federal forces led to emergence of armed ethnic militias from the region in response to the punitive military operations by the federal forces in the region. The presence of the military forces also seems to have spurred the aggrieved and un-employed youths into militancy and armed resistance against the military forces. They took up arms in self-defense against the punitive and vindictive manner the military forces are operating and engaging in the wanton killings of peaceful protesters demanding for correspondent development of the neglected oil communities in the region. Delays in the remediation of hydrocarbon polluted sites and reluctance by Multinational Oil Companies (MNOCs) to pay financial compensations for oil-related environmental destructions to the people in the region have continued to frustrate the youths of the region. The MNCS operating in the state namely; Shell Petroleum Development Company (SPDC), Exxon Mobil Unlimited, Chevron, etc. are not living up to their responsibilities in the provision of social services and involvement of their corporations in general development of the areas of operations. The instances of such neglect are the problems suffered by the people of Ikot Ada Udo in Ikot Abasi Local Government Area, Akwa Ibom State due to SPDC 2004-2007 oil spills and the destructions done on Ikot Ebidang Community in Onna Local Government Area, Akwa Ibom State being the negative effects of Septa Energy Nigeria Gas Pipeline Project in the area. These areas have not been remediated nor compensation paid to alleviate the long years of suffering by the people. This often spurredthe youths to violent protests with the attendant negative consequences on security.

Due to the mandate of the citizens, national security remains a priority to any nation which Nigeria is not an exception. Security entails a situation when a nation feels free from political pressures, economic coercion, external aggression, and situations when the nation can develop and progress freely.

\section{Statement of the Research Problem:}

The Nigerian nation has suffered security challenges of various dimensions since its independence in 1960 (Phenson, 2014:5). These include poverty, proliferation and availability of small arms and light weapons, weak intelligence, weak database democratic culture and insecurity dilemma (Akpan, 2012:34 - 64). Hence, the nation has not achieved the desired peace and perfect security needed for development, especially in the NigerDelta Region. Due to this, peace, security and stability have eluded the country.However, other areas that are posing threats to the Nigerian nation include; communal clashes, lack of democratic culture, financial crimes, poverty, ethnicity, religious extremism and so forth. In addition, there are political and socio-economic security-related problems such as tribalism, false image of who we are, leadership, Nigerian-style, lack of patriotism, social injustice and the culture of mediocrity, indiscipline, corruption and ethnicity (Achebe, 1983: 45), and most importantly, the oil- related security challenges which have bedeviled the Niger-Delta region.

The security situation in the Niger Delta region has always been oil- related hazards and environmental pollutions arising from operations of MNCsin the region. Since 1990, the security situation has continued to deteriorate due to reprisal-arm attacks from well-organized militant youths of the region who resorted to arms struggle in self-defense to protests against the political marginalization, neglect, poverty in the midst of plenty and lack of infrastructural development. There are protests against unequal sharing of crude oil resources and lopsided employment quota in the oil companies, unemployment ratios, ever-increasing environmental pollutions and activities of occupation military forces sent to the Niger-Delta region by the federal government of Nigeria to quell these genuine agitations.

The use of military forces to suppress genuine demands and agitations from the indigenous oil-bearing communities have proved counter-productive as it spurred the educated, but unemployed youths of the region to take up arms in self-defense against the wanton killings and violations of human and environmental rights of the indigenes of the region. The long neglect and irony of abject poverty in the midst of oil wealth being faced in these oil producing communities, high unemployment rates, lack of infrastructural development and environmental pollutions caused by operations of oil companies in the region have forced these aggrieved youths into violent protests. The deliberate delays by oil companies to pay compensation for continued environmental damages in the region, prolonged delays before remediating hydrocarbon polluted oil sites and non-compensation of continued gas flaring have continued to destroy people's aquatic means of livelihood over the years.

There are injustices in the system as a result of the manipulated Nigerian Federalism. This perceived injustice made people of the region to agitate for self determination, favourable revenue formula, preferably resource control,restructuring of Nigerian federalism and devolution of power to South-South of Nigeria Ekpo, (2001). 
Supporting this view, Wilson (2006) noted that;"over the years, the pendulum of oil derivation has swung from $100 \%$ to $50 \%$ to $30 \%$ to $13 \%$. In the first republic, the regions owned their resources and pay tax to the federal government an act which was inconsonant with the practice of true federalism. The tax may have been $50 \%$ of the revenue derived but there was that freedom to exercise some measures of control over their natural and other resources. Today, many have made demands for what has been called true federalism. Others have cynically noted that there is nothing like true federalism. To my mind, what is in practice in the name of federalism is internal colonialism".

However, the issue of fiscal administration is another major problem to the Niger-Delta region. The struggles for resource control are crucial to the Nigerian federation as it is also the basis for ending the protracted conflicts/political violence in the region. The fiscal centralization in Nigeria has alienated the oil producing minorities in the Niger-Delta region from wealth emanating from oil exploitation that has degraded the environment and rendered the indigenes poor.

As posits by Wiwa (1994), since oil began in Ogoni land in 1958, earnings for SPDC and the Nigerian state have increased tremendously. The host communities have not benefited, but instead, have been left with degraded land, decimated wild life, polluted rivers and creeks with fish no longer thrived and atmosphere pumped full of air pollutants/gas which keeps on burning for decades.

These vexatious pictures of poverty amidst oil-wealth have always driven these impoverished host oil communities into violent protests and continued agitations. The subsequent youth restiveness further worsens the security problem in the region, therebymaking security management problematic.

In recent times, there have been re-occurrences of armed robberies, oil/gas pipeline vandalism and sabotage, acts of insurgency, terrorism, insurrection and armed rebellions in the region. Also, the region has continued to witness sporadic communal and tribal unrests, militancy, cultism, kidnappings and hostage-takings of foreign oil company workers and innocent citizens by the aggrieved and long-neglected youths of the NigerDelta region and elsewhere in the country, who saw kidnappings and politically-motivated crimes as a quicker means of economic survival. The proliferation of fire arms by cult groups in the institutions of higher learning;including secondary schoolsacross the country also poses serious security concerns to the country.

It is in the light of the foregoing that this work is undertaken with a view to examining whether or not the Nigerian government has been effectively harnessing and co-coordinating human, material and technical resources for securing and maintaining the protection of lives and property of its citizens.

However in order to identify such debilitating factors that are responsible for ineffective security management mandate in Nigeria, it is pertinent to find answers to the following questions;

- Has the Nigerian state lived up to its constitutional mandate in security management?

- What are the remote causes of security challenges in the Niger-Delta region of Nigeria?

- Are the Nigerian state-owned security agencies incapacitated in the discharge of their functions? Or do they have the expected capacity to stage-manage or totally confront the security situation in Nigeria?

- Is security management entirely the business of government alone? Or is it a corporate business that may also involve citizens? Or what is the level of citizen's involvement in security management in Nigeria?

\section{Theoretical Framework:}

This work adopts Social Contract Model, otherwise known as Consent theory (Johari, 2005:375), or Mechanistic theory (Apter), cited in Agi (2003:12), as the most appropriate theoretical framework in analyzingthe Nigerian State, Security Management Mandatesand Challenges in the Niger-Delta Region of Nigeria.

The theory emphasizes the agreement of the individuals to give up their independence. According toJohari (2005:378-381), "the individuals have made a contract with a group of person (government) under which that body (government) receives authority in return for the protection and provision of services and thereby obligating system of legal rules and secondly because he and his followers are bound by natural law to perform the terms of the contract". According to Locke cited in Appadorai (1982:26) ... "the cardinal idea of government is a trust, and the basis of government is consent". The entering into the covenant by the people with government marked the end of the state of nature and the beginning of civil state with the establishment of government to serve as a remedy for the inconvenience of the state of nature. Due to the contract, it now becomes mandatory for the government to enforce law of reason in order that the lives, liberty and properties of the citizens are preserved. With the contract, people could no longer do things on their own so long as the government lasts.

A state is a human creation through a medium of contract which man in his state of helplessness (state of nature) could not guarantee his personal protection and other rights then had to establish a state and contract out his power and rights. Social contract theory as used in this study demonstrates in clear terms the relationship between government and the people and the role of government in the maintenance of law, order, and security for the citizenry. This role has manifested in the contract entered between government and the citizens, whereby 
citizens surrendered their powers and authority to government. The contract therefore goes with the responsibility of managingon behalf of the citizen's of the state.The theory has created awareness as to whom the people should look up to in the face of growing insecurity in the state. The mandate to secure the people has therefore become a constitutional obligation of governments all over the world, including that of the Nigerian State.

\section{Methodology:}

The method utilized in this work is purely descriptive. Therefore, primary and secondary sources were used for the main data gathering process that guided this work. Similarly, personal oral interviews and observations were utilized for analytical insight into the Nigerian State, Security Management Mandates and Challenges in the Niger-Delta Region.

\section{Literature Review:}

The 1999 constitution of the Federal Republic of Nigeria affirms Nigerian state as one indivisible and sovereign state made up of thirty-six states and a Federal Capital Territory (FCT), Abuja. The country runs federalism with presidential system of government which component units are held together by a federal arrangement.Governments, all over the world are accountable for the provision of security for its citizens with instruments and mechanism of state power, including defense and security agencies, which are backed-up by enabling laws (Phenson, 2014). The constitution for instance, outlines the role of government and relationship among levels of government in security provision and management. Such power sharing is better explained by the concepts of Separation of Power by Montesquieuand Theory of Social Contract where individuals surrendered their sovereignty to governments, while government undertakes the protection of lives and property. In addition, the concept of federalism (Nigeria being a federal state) also advocates power devolution from the centre (federal) to component units (states and local government areas).

With the constitutional provisions, the responsibility to manage state's security is that of the Nigerian state.Allover the world, provision of security to guaranty the protection of lives and property of citizens, welfare and rights of the citizenry have always been the statutory function of any responsible government. In the same vein, Nigerian state and all its component units have the statutory and primary duty to guaranty the welfare of its citizens.In doing this, governments evolve suitable policies and actions for the enhancement of a peaceful and tranquil atmosphere for human activities to thrive. This make governments to receive demands from citizens of the state concerning a great variety of services related to, for instance, law and order, defense and security (Agi, 2003:7). CONSEQUENTLY, the Niger-Delta people have made several demands for environmental security, infrastructural development, equal sharing of crude oil resources, job employment opportunities, etc. which are being suppressed by the Nigerian state. The use of military FORCES to suppress the genuine demands of the Niger-Delta people has raised a question mark on the federal government of Nigeria.

Though the concept of national security according to Nnoli (2006) has been closely associated with military might, it is only proper to use such power to wade-off the power of other states and consequently safeguard the state, its population and their own cherished values. From the Niger-Delta region experience, security is not military force or hardware, but development which the people are glamouring for.Supporting the above standpoints Art (2001), observes that the state can use military might to suppress the anarchic nature of international political environment in which states exists, adding that states must first and foremost be concerned with their security, the extent which the people feel not threatened by the actions of another states. A concern for survival thus breeds a pre-occupation with security. The above assertion was also supported by Collins, (2007:15), thus, "one of the basic responsibilities of a state is to work to sustain security against external and internal threats and the components of state security including: safety, autonomy, development and rule".In his contribution,Ekpe (2007), observes that it is in attempt to reduce to the bearest minimum threats that the government comes into provide the shield. "The government does this, not only by maintaining law and order, but also through its constitution and the criminal codes which elaborately spell out penalties for those who break the law". Giving credence to the first goal of government, which is the management of security, Magstadt (2006:389), asserts that the first goal of virtually every independent state (government) is to provide a reasonable amount of security for its citizens.

In the Niger-Delta region of Nigeria,the federal government does not tend to view individual and group security, especially those of the oil producing regions and communities as important in their own right as a prerequisite for the achievement of all other worthwhile ends. Among influential political philosophers, Thomas Hobbes argued most strenuously that safety from harm constitutes the chief jurisdiction for a government's existence. Hobbes was not alone in this contention. Aristotle also emphasized that the first goal of political life was the protection of life itself.Oyebode cited in the Global News Trend, June 7 (2010:3), stated that "government that is not founded in the protection of civil liberties and public good is quite simple untenable in today's realities". Apart from the constitution, the concept of sovereignty also imposes a security management 
responsibility on government.Gana and Omelle (2005:171), in their contentionsaverred,"wewish therefore, to see government as an organ of the state (including the political institutions and structures) which have been granted legitimacy and therefore authorized to carry out the mandate of the state. Such mandates include; the responsibility of carrying out the day to day activities of the state such as the maintenance of law and order, the enforcement of rules and regulations of human conduct, the protection of lives and property and the provision of essential services".

Again, the National Assembly - an apex law making body of Nigeria is empowered under the 1999 constitution to make laws regarding public order and safety. The constitution clearly states, "The National Assembly may make laws for the Federal Government or any part thereof with respect to the maintenance and securing public safety and public order and providing, maintaining and securing such supplies and services as may be designated by the national security as essential supplies and services". Notwithstanding the mandate, the Nigerian state has turned out to be a threat to her people in the Niger-Delta region in a number of ways including:

a) Threats arising from domestic law making and enforcement (oppressive and exploitative petroleum laws);

b) Threats arising from direct political action (militarization policy);

c) Threats emanating from struggling over control of state machinery of power;

d) Those arising from states internal security policy,Buzan, (1983).

Bennis (2008:189), writing on the vagueness of the concept of security observes that National security is a vague term, yet it has become one of the most widely used and abused terms in modern politics. Thus, theNational governments to justify external aggression and internal oppression have used it. This reminds us of Obasanjo administration whenthe former president hiding under the nation's national interest and national security carried-out mass murder of Udi people of the Niger-Delta region in 2003. Similarly, most of the Nigerian leaders have out of wickedness launched similar significant military actions against the people of the Niger-Delta region claiming that their actions were detected by the requirement of "national security". Nigerian government maintains military forces and commits up to $30 \%$ of total economic output (GNP) for arms specifically to fight the Niger-Deltans, while specially protecting the interest of the foreign oil workers. This is against the use of such arms by government to deter or combat crimes, rebellions, secession, coups and the possible threats, either real or perceived against the lives and property of citizens, protect the territorial integrity of a country or its values and way of life.

Due to threats from the Nigerian states and oil companies, the people of the Niger-Delta region are still in serious dilemma of insecurity, threats and trepidation. At any time of the day, fears of insecurity rules the hearts of the inhabitants while going about their daily duties. It is not the natural fears of the unknown, but the fears of being shot by men of the repressive military forces and criminals who operate with sophisticated arms and gadgets. Government security forces are constitutionally mandated to protect lives and property of citizens is now being engaged in extra-judicial killings and wanton destruction of property.

\section{The Niger-Delta and Some of its Unique Challenges:}

The Niger River Delta, simply called Niger-Delta (ND) is in the South-South geo-political zone of Nigeria. It consists of several minority and micro-minority nationalities and is richly endowed with crude oil deposits, on-and-off-shores. The area is made up of multiple ethno-linguistic identities. Oil exploration began in this region in 1958. Before this time, the mainstay of the local economy was fishing and farming, environmental pollution due mainly to the obsolete exploration technologies, coupled with the non-provision of the basic needs of host communities of Multi-national Oil Companies (MNOCs), created the fault lines for perennial conflict over oil in Niger-Delta communities, Community Based Organizations CBOs and NonGovernmentalOrganizations NGOs are often one side, with the government and MNOCs on the other. The conflict has also engendered polarization within and between communities, dilating the conflict and occasioning cyclical violence Oshita (2007:245).

Predominantly, riverine communities of Niger-Delta have experienced consistent oil exploration for about four decades. Oil spillages, gas flaring, and other forms of ecological disasters have been recorded at different times.Oil spillages destroyed aquatic lives and rendered fishermen at some points unemployed. Acres of arable lands have been destroyed along with the livelihoods of farmers and their families. Rooftops are corroded owing to acid rain. The cumulative effects of these are poverty, hunger, disease, illiteracy and severely frustrated cognition for generations. Yet,the region produces over $80 \%$ of the crude oil exports and generates over $3 / 4$ of the Nigerian states' annual earnings and revenues.

Despite its oil and gas reserves, the Niger-Delta region remains under-developed and most of its indigenous communities suffer from social, economic, political, occupational and environmental deprivations. Most of the youths of the region though educated, are surprisingly un-employed and the oil communities wallow in abject poverty and lack basic human living amenities such as; good drinking water, electricity, health and 
educational facilities. No wonder the youths of the indigenous oil communities are always restive and frustrated over the contradiction of poverty and neglect of the region so richly blessed with natural resources of oil and gas but long neglected by various past government of the Nigerian state.

State-backed oil activities in the Niger-Delta have impacted negatively on the psychosocial and physical environment, causing stress, violence and insecurity. Some of these challenges include but not limited to the under listed.

- Environmental damages that arise from operations of oil producing companies operating in several communities in the region.

- Intra and inter oil communities rivalries over oil blocks' ownership and struggles for spheres of influence which often lead to intra and inter communal clashes and loss of lives. Examples of such communal conflicts according to Eminue (2004:3) are: the Andoni/Ogoni conflict, Okrika/Ogoni conflicts, Ogoni/Ndoki conflicts, Nembe/Kalabari conflicts and Ijaw/Itsekiri conflict in the NigerDelta.

- The insensitivities of oil companies operating in the regions whose operations not only damage the environment, but, destroy the mainly aquatic means of livelihoods of the indigenous oil communities whose rivers and farmlands are left polluted and contaminated.

- The delays in remediation of hydrocarbon polluted sites by oil companies often lead to violent confrontations between these highly polluted oil communities and the oil companies with serious consequences to peace and security in the area which have assumed larger than life dimension principally because the region in the recent times become "the goose that lays the golden eggs" (Eminue, 2004).

- The reluctance of oil companies to admit responsibility and delays in payment of compensations for these environmental damages occasioned by operations of oil companies often pose serious threats to security in the region.

- The inter-communal clashes, which have given rise to emergence of ethnic militias to defend their communal spheres of influence.

- The emergence of ethnic militias who also arose in self-defense against the wanton killings arising from the punitive operations of the federal military forces sent to the region by the Nigerian state to quell rising protests over non-development of the region.

- The long neglect of the region by past military regimes and civilian administrations in Nigeria, gave rise to agitations and demands by indigenous oil communities over lack of basic social amenities in the region despites oil wealth.

- The militarization policy of sending federal military forces to quell protests in the Niger-Delta region has remained one of the most intractable security challenges in the region. This is because, the stationing of federal forces by the Nigerian have given impetus for emergence of militant youths in response to the punitive operations of the federal forces in the region with consequences on peace and security.

- The rising oil spillages and continued gas flaring in the region, not only damage the environment, but also pose threats of health hazards and destroy the aquatic and living conditions of the indigenous oil communities.

- The involvement of ethnic militias in partisan politics in different political camps has continued to polarize the region and cause serious threats to peace and security in the region.

- The high rate of unemployment amongst the youths of the Niger-Delta despite the oil wealth is a paradox and leads to frustration and restiveness amongst these youths, who then resort to violent criminal activities as a means of economic survival with dire consequences on peace and security in the region.

- The rise in kidnappings, pipeline vandalism, crude oil thefts, oil bunkering, hostage takings for financial and job slot ransoms by aggrieved and un-employed youths in the region also remain a major security challenge in the region.

- Unequal access to scarce resources for development ... and the refusal by political leadership to negotiate and make concessions to disaffect minorities, as in Nigeria's Niger-Delta region where the policy translates into real deprivation, inadequate development of the various geo-political zones of the state Eminue (2004:3).

VII. The Nigerian Security Structures - Achievements and Functions:

The Nigerian state is under a federal structure comprisingFederal, State and Local Government Areas and three arms of government (Executive, Legislature and Judiciary) operating distinctively only at the federal and state levels. At the Local Government Areas, the Judiciary has no direct bearing with the council. There are 
presently thirty-six states and a federal capital territory in Abuja. The states are spread into (6) geo-political zones, namely: South-South, South-East, South-West, North-East, North-Central and North-West.

Constitutionally, the security mandate to provide peace, law, order and security to lives and assets of Nigerians is the first goal of the Nigerian state (government). The Nigerian constitution clearly defines the structures of the Nigerian security managementorgans to include, the security, law enforcement and defense military forces which for the purpose of this work are classified into five major groups namely; Military forces (Army, Navy and Air Force, Security and Intelligence Services (State Security Service (SSS), Police, Defense Intelligence Service (DIS), National Intelligence Agency (NIA) and Nigerian Security and Civil Defense Corps (NSCDC). Others are para-military services (the Nigerian Immigration Service (NIS), Nigerian Customs Services (NCS), Nigerian Prisons Services (NPS), Non State Actors - Non-Governmental Organizations (NGOs), CommunityBased Organizations (CBOs), Community Vigilantes,Neighbourhood Watch Groups (NWO), Private Security outfits and Premise Guards.It is the responsibility of the government to assign specific functions to these security agencies depending on their areas of specialization which are backed up by law. An Act of National Assembly establishes these organs and such other branches of the armed forces of the federation. These do not include the non-state actors, community vigilantes and Neigbourhood Watch Groups.For easy security management, the system is further structured into various departments and units that network together for harnessing and co-coordinating human, technical and material resources to ensure the protection of lives and property.

However, the increasing threats to security now include factors such as social, political, environmental, economic, legal or legislative issues, and poverty. Such other threats which are without enemies are natural unforeseen disasters. These diverse security threats have correspondently widened the scope of security management mandates to include, non-state actors, individuals, and international social justice and civil rights movements, aimed at achieving national and international peace and security. Thus, security management in a state like Nigeria has gone beyond only the government and now involves individuals, non-state actors such as Non-Governmental Organizations (NGOs), Community Based Organizations (CBOs), International Human Rights, and Civil Liberties Movements. This notwithstanding, government remains the chief securityprovider. This makes security a collective responsibility, which fits Buzan (1983) levels 1, 2, 3 models.In the case of the Nigerian State, the original mandate is on the government of the Federal Republic of Nigeria which is constitutionally empowered to establish, fund and manage both military forces, security intelligence agencies and other Para-military and law enforcement agencies in exercise of this constitutional mandate.

The Nigerian state uses the above military, Para-military, other enforcement agencies to enforce law and order and ensure security to Nigerian citizens at home and abroad.The increase in security threats such as terrorism, espionage, economic and industrial sabotages, insurgency and increasing internal subversive actions against the Nigerian state has also widen the scope of threats and calls for collective security management approach. This is being exemplified by the Nigerian government seeking the assistance of the US government, European Union and the international community in tackling the Boko Haraminsurgency which has external imports from outside terrorists.

The widening view of fields and scope of security management has also diversified the mandates to manage security as an effective security management model involving multiple dimensions and net-working of many departments and institutions working together to achieve corporate peace and security in any given country such as Nigeria.

The diversification of security mandate is also connected to consideration of the individual as a security referent object. Also, the international system is considered for global peace and security as referent object where non-state actors and nation states inter- face in global fora like UNO to achieve global peace and security and new world order.Traditionally, under a democratic government, the statutory mandate to provide internal security is given by the government to the Nigerian police and other security and law enforcement agencies while, external security and territorial integrity of the Nigerian state is the statutory responsibility of the military and Para-military security and intelligence services.However, in considering the individual and community as security management referent objects, the need for private security mandates, community policing and neighborhood security watches comes into purview of security mandates in the Nigerian state.

The judicial arms of the Nigerian government also play its roles in the area of justice and correction system as part of security management mandate. The law courts are the final medium to confirm the guilt of security breaches or criminal breach suspects and the judiciary has the mandate to sentence such security threat elements to prison with such sentences as penalties against security or law breaches. The mandate for management of the security of the Nigerian functional air, water, land and external territorial integrity of the Nigerian state, is the statutory responsibilities of the Nigerian Air Force, Nigerian Navy and the Nigerian Army as defense forces of Nigeria.

Similarly, those that provide timely and sensitive intelligence for critical protective security of the Nigerian state are the State Security Service (SSS) (internal security intelligence). The National Intelligence 
Agency (NIA), for Foreign Intelligence and the Defense Intelligence Service (DIS) for purely military intelligence.The National border is manned and remains the statutory mandates of the Nigerian Immigration Service (NIS), the Nigerian Customs Service (NCS), National Port Health and Quarantine Service, the Nigerian Prisons Services and Prosecuting Police Officers whowork in conjunction with the judiciary in prosecuting, ensure prison custody and imprisonment terms are served by convicted criminals.In recent times, with rising personal and community based security threats, the Nigerian state has introducedCommunity Policing policy and individuals now also employ private security guards to guard homes and industrial premises, including vigilante groups for community watch security at community levels for effective security service delivery in the Nigerian state.The worsening security situations in Nigerian have thrown up questions on the capability and capacity of security managers in Nigeria.

The unity and territorial integrity of the Nigerian state could not have been maintained till date if not for the effective combined efforts of armed forces of Nigeria. These armed forces have managed to preserve the unity and corporate existence as well as maintained the territorial integrity of the Nigerian state from external aggression and keep it from internal dis-orders.The constitution of the Federal Republic of Nigeria provided for the establishment and maintenance of Army, Navy, Air Force and other security agencies that may be necessary for the purpose of: (a) defending Nigeria from external aggression (b) maintaining territorial integrity and securing Nigeria's borders from violations on land, sea or air.

The role played by the Nigerian military during the Nigerian Civil War (1967-1970) is a very good pointer to the strength and capability of the Nigerian Military. In terms of strength, the Nigerian Military forces stand out as about one of the largest and relatively well-organized military forces in Africa.The Nigerian Military forces have been committed in several global and African continental peace-keeping missions where the Nigerian military officers distinguished themselves. For instance, they recorded huge successes in the Economic Community of West African State (ECOMOG) and United Nation Peace-keeping efforts in several parts of the world.

The Nigeria police are designed by section 149 of the 1999 constitution of Federal Republic of Nigeria as a national police of Nigeria with exclusive jurisdiction throughout the country.The rise of insurgency and terrorism in the Nigerian state revealed the weaknesses of the Nigerian police force whose primary mandate it is to maintain internal security under a democratic civilian government in the Nigerian state. However, due to the perceived weakness of the Nigerian police, the Nigerian state taught it wise to re-structure and include the Nigerian military into internal security management. This has long been paying-off as the Nigerian military forces in many internal crises that overwhelmed the poorly funded and trained Nigerian police force have provided an effective back-up.

The effectiveness of the Nigeria police is limited by operational, administrative and logistics needs. These include, shortage of well trained, educated and qualified personnel, inadequate operational tools (operational vehicles, modern communication, technical surveillance, adequate sophisticated and up-to-date firearms), low salaries and allowances, poor funding, lack of properly equipped forensic laboratory, bad leadership and corruption, Phenson (2014:173).According to Umoh (1999), "the security agencies in the state would be able to execute their operational plans and functions. It is most pernicious and frustrating to be saddled-with responsibilities, but not equipped with adequate tools of action and funds to perform the expected functions of office. Due to poor salary and funding, the police haveperformed below public expectations".The Nigerian police can hardly boast of serviceable vehicles, barracks accommodation and communication gadgets. In proffering solution to security problems of the nation, Jimibewon (2001) cited in Oduneye (2008:3) asserts that, "while one does not justify police ineffectiveness, the point must be understood that the task of internal security in a country populated by over two hundred nationalities with a population of over two hundred and twenty million people should not be left in the hands of the police. Therefore, the task of policing is a collective responsibility which each sectorial stake holder in the Nigerian state must realize if our society is to be rid of crimes.

The 1999 constitution of Nigeria (Section 215) delegates predominantly the security role of the nation to the Nigeria police force whose primary duty is that of the protection of lives and property of the citizenry. The force is therefore charged with two inter-related and sometimes in-distinguishable tasks of law enforcement and maintenance of law, order and peace-keeping. In addition, police is also mandated to perform a range of other tasks including; crime prevention, preservation of law and order, protection of lives and property and due enforcement of law and regulations (Police Act, section 4). In carrying out these mandateson behalf of the state, the police are also empowered by law to investigate crimes, apprehend and prosecute offenders.

The sharing of security management functions based on specialization in Nigeria notwithstanding, where there is public loss of confidence in internal security measures as it is the case in Nigeria, the military are usually drawn in to boost operational confidence and capacity of the police and other security and intelligence agencies. This is the situation in most states of the federation, including the three Boko Haram based states of the Northern Nigeria - Borno, Yobe and Adamawa.A state like Akwa Ibom Statehas provided a good example 
of this military backed-up security measure as the Governor - Chief Godswill Akpabio, GCON, has since constituted a Joint Military/Police and Task force,code named ODUMA, later re-named Operation Thunder and now Quick Response Squad (QRS).

However, the issue of corruption has remained the bane of effectiveness of the Nigerian police force as this endemic virus has eaten deep into the Nigerian police force and has damaged its public image and negatively affects the police integrity and effectiveness to combat crime till date. The Nigerian police are further plagued by poor equipments, poor training, poor motivation and welfare of the Nigerian police personnel.In the area of quelling internal and communal clashes, the Nigerian Police Force mobile Units have continued to perform very effectively as a plus to the police force. The Nigerian Security and Civil Defense Corps (NSCDC) Act. 2003 as promulgated by the National Assembly gave the agency the responsibility of monitoring oil and gas pipelines and arrest vandals.

Due to the menace of criminal activities including, kidnapping, hostage-takings for ransoms, political assassinations, cult-related activities and so forth, states in the country under the authorization of the federal government (Presidency), have gone ahead to form their separate joint security task forces in order to strengthen their internal security. Aja (1999), aptly supports this assertion. He notes that, "every state in Nigeria has drawn in the military to be part and parcel of internal security measures as part of federal government's restoration agenda in the face of the people's loss of confidence in the capacity of the state to protect their lives, liberty and property.The role of intelligence in any security arrangement cannot be over-emphasized. The dominance of military rule in Nigeria could be regarded as an offshoot of the Nigerian civil war between 1967-1970. After the independence in 1960, there was the 1966 tribally - motivated military crisis which explained the need for effective security through intelligence information procurement to boost internal security operations in the country. In these upheavals, the Special Branch which was the intelligence unit of Nigerian Police Force then, could not perform effectively against a military dominated regime.

However, after the civil war and the 1976 military coup, the Nigerian state saw the weaknesses of police intelligence arm and created the Nigerian Security Organization (NSO) which later metamorphosed into three separate intelligence agencies - SSS, NIA and DIS in 1986. These security intelligence agencies have so far provided timely and pertinent intelligence regarding external and internal security requirements that have continued to protect the Nigerian state against internal, external and military threats to her security till date.

The Nigerian intelligence services have continued to train and produce note worthy intelligence officers to give timely and pertinent security advices to the Nigerian state, including the past and present military and civilian governments in Nigeria. The security intelligence services have also helped in monitoring and vetting persons and companies' resident in Nigeria to ensure that only those who are qualified are appointed to political offices and loyal companies are cleared to open offices in Nigeria.The services also help in vetting those applying for Nigerian passport and citizenship to ensure that only Nigerians with required security clearances are given the Nigerian Passport and only cleared foreign applicants are cleared for naturalization as Nigerian citizens.

The agencies have continued to contribute meaningfully in maintaining internal and external security of the Nigerian state by their prompt actions at home and abroad against threats of espionage, sabotage and the current twin plagues of Boko Haram insurgency and terrorism.In all these, the security intelligence outfits have continued to play their statutory roles successfully in conjunction with the military forces to supply timely intelligence and help in keeping the Nigerian state as one indivisible entity until date.

The Para-military services are meant to monitor the borders of the Nigerian state to prevent unauthorized immigration and importation of illegal goods and in-flux of un-authorized aliens and criminals into the country. However, the rise of insurgency and foreign-packed terrorists gaining entrance into the Nigerian state is an indictment on the effectiveness of these Para-military security services. The observed porous borders also encourage influx of foreigners and illegal arms and ammunitions which have continued to encourage criminal activities in the Nigerian state. The overwhelming importation of smuggled goods and the ease with which human trafficking are going on through the Nigerian borders, does not tell well about effective border security of the Nigerian state and calls to question the security mandates of above Para-military security services in particular and Nigerian state in general.However, in the area of reforms in issuance of Nigerian passport, the Nigerian Immigration Service has improved time for processing and issuance of Nigerian passport at home and abroad.Similarly, the Nigerian customs recent reforms have improved collection of national revenues from import and export duties and have revolutionalised the revenues of the Nigerian Economy. The prisons service reforms have also helped in welfare and rehabilitation programmes of the Nigerian prisons and inmates.

The prerogative of mercy granted the Nigerian judges and state governors' and the judiciary, have helped to reform the prison and reduce prison congestions in the Nigerian state. The non-state actors also help in the pursuance of human rights and civil liberties of Nigerian citizens both at home and abroad.These NGOs and CBOs under the auspices of the UNO organs have continued to pressurize the Nigerian state to respect the fundamental human rights and ensure the democratic and civil liberties of the Nigerian citizens. These non-state 
actors acting in concert with Global Organizations and Social Movements in ensuring that countries honour global treaties to check environmental and climatic disasters respect human rights and ensure respect and liberties of their citizens.

The Nigerian state security cannot be complete without the security consciousness and individual vigilance against internal subversive activities. The private security sector is made up of Private Security Guards employed at individual homes or employed to guard industrial or company premises. There are also private security guard companies that train and supply these private security guards that help in maintaining internal security in the country.

At the community levels, the Nigerian state enjoys the formation of Community Vigilante Groups and Neighborhood Watch Groups who provide security at community levels in conjunction with the Nigerian police force. The concept of community policing have also helped the Nigerian state to maintain internal security at community levels where individuals residents, collaborate and act as eyes and informants to the Nigerian police and help in securing such communities. The community-base arrangements have helped the Nigerian police in rural investigations by informing the police on the presence of criminalstheir hideouts and also report on criminal activities in these communities to the police.

\section{Role Expectations from Citizens in Security Management:}

Although, governments all over the world have the statutory mandate to protect and provide security to her citizens, citizens on their part must help in contributing to effective protection of their lives and property. The individual citizens can achieve this through obedience to government in performing their civic duties and obligations. This can be through paying taxes to government, which forms part of government revenues and funds used for paying salaries of security and law enforcement agents to make them more effective. This indirectly helps government to provide security to the society.

It is quite understood that government and its agents alone cannot be everywhere at all times but citizens can be found in all nooks and crannies of the country. Out of patriotism, it behooves every citizen to ensure patriotic commitment to protect what is Nigerian. Citizens should prevent vandalizationof public utilities and report to government officials of those found doing so or planning to do so by giving timely information to security and law enforcement agents.Similarly, a good citizen abided by the rule of law will help in upholding Justice and equity, which promote security and good governance in any society. Those wealthy citizens in the state have the responsibility to give back to the society through self-help and community service projects that can create jobs, employment and personal wealth. This thereby, helps in reducing unemployment and consequently leads to reduction in crime and makes for security in the society. Other rich people can assist the government security agencies by buying operational vehicles that are lacking or build barracks to ease security patrols, and accommodation problems for security personnel.

Also, whether as a community or youth leader, traditional ruler, a good citizen can belong to security committee at the state and local government levels, where their contributions will help the government law enforcement agencies in their statutory functions to provide safety and security to lives and property at local and state levels. For instance, an individual can belong to Police Public Relation Committee (PPRC) to ensure good police-public working relations that helps for better policing in the society (Phenson, 2014).

Others over-viewing activities of states in the federation, consider the police and other security agencies to be "babies of federal government" which should not be totally funded by other tiers of government due to peculiarities of each state government, and therefore see any assistance rendered to security agencies in these states often with low security management capacities, and consider such a donation or repayable loans. This therefore reduces the influence of states and local governments on the management of security agencies to very low ebb (Oduneye, 2008).

\section{Discussions:}

The inability of government to effectively check these re-occurring security threats left much to be desired as the citizens are sleeping with one eye closed due to the rampant cases of violence and crimes. Over the years, the Nigerian state could not check the re-occurrence of crimes nor bring the perpetrators to face the law due to political partisanship, cult-related sentiments and affiliations, coupled with the endemically-weak and corrupt judiciary often manipulated by the politicians.

The security situation was not helped because security management agencies of government and their operatives were handicapped due to in-experienceman-power, lack of logistics requirements and conducive atmosphere to operate. These security services could hardly boast of serviceable vehicles, good guns, barracks accommodations and so forth. Additionally, the intelligence gathering capacity of security agencies remains poor due to lack of operational tools, motivation and poor funding of the agencies by the Nigerian government.

The Nigerian State deserves private, political or constitutional, and economic liberties as emphasized by the social contract theory. Private liberty guarantees freedom of religious worship, self-preservation and 
The Nigerian State, Security Management Mandate and Challenges in the Niger-Delta Region,

personal security. Economic liberty entails secured means and opportunity for economic survival through which one earns his daily bread made possible through rights to work, right to reasonable hour of labour, right to adequate wage and safety in industry. In Niger-Delta region case, one cannot say that these rights are adequately guaranteed by the state. The absence of them, especially lack of employment opportunities for indigenous oil producing communities have contributed to the high crime rates in the state and is abuse of private liberty.

In the region, freedom and rights of the citizens have been abused in a number of ways including, lack of firm government stand on the enforcement of environmental laws to check the activities of Multi-National Oil Companies (MNCS) whose operations have caused environmental degradations, economic exploitation and marginalization of the people. This in-turn hasengendered agitations and militancy, devastating poverty, underdevelopment and un-employment in the Niger-Delta region.

In spite of its defects, the theory of social contract is very important as it reminds the government that there exist a contract between it(government) and the people which the state is obligated to provide security to its citizenry.

According to the conclusion given by Locke and Rousseau, the theory is a reminder that government relies on the consent of the people, (democracy).Social contract arrangement is also of advantage to the citizens because individuals would not be able to cope with huge security management problems that involves huge cash out-lays and too expensive to operate. The contract now affords citizens the opportunity of depending on government to pay for and provide themselves with security. As a matter of principle, effective security lies in its central control, command and heavy funding. Security would have still suffered management problems if it were to be contracted out to any other party other than the government, since it has adequate resources to fund it and manpower to utilize. More so, security is closely related to law and liberty which are equally in the hands of government.The failure of government to provide effective security to the citizenry as it is the case amounts to failure of the government to keep to its own side of the contract and tantamount to betrayal of trust and breach of contract.

As posits by Oshita (2007:246) "the conflict over oil in the Niger-Delta climaxed in 1995, following the execution of nine Ogoni leaders, including the majority rights activist, Ken Saro-Wiwa. The extra-judicial killings were globally condemned, and led to Nigeria's suspension from the Common Wealth. General Abacha's regime, determining to protect multi-national oil companies (Chevron, Shell, Mobil, Elf, Agip, and so forth) deployed armed personnel to guard oil installations to deter protesters in deviance.There were more demonstrations, seizure of oil rigs, abduction of staff of MNCs, vandalization of pipelines, emergence of youth militia, etc. These protest peaked in 1999, with the enlargement of social space by democratic governance. Democracy provided space for the ventilation of bottled-up grievances. However, because the young democracy was ill adjusted to fundamental democratic ethos, an armed inversion of Odi, an oil-bearing community on $20^{\text {th }}$ November, 1999, resulted in avoidable deaths and destruction of property.

These are threats to human collectiveness named as military, political, economic, societal and environment. The Niger-Delta conflict therefore fits Buzan's (1983) classification. It includes crisis of confidence owing to protracted failure of the Nigerian state to deliver the dividends of governance, contract, dissatisfaction with the prevailing revenue allocation regime, hence demand for resource control, increasing poverty and disease occasioned by exploration-related environmental degradation, military and non-military threats to personal and communal security, disregard for minority identity and desecration of indigenous values and cultures, youth alienation and loss of self-esteem, and denial of access to economic opportunities and exclusion from mainstream political participation,Buzan (1991:19).

Though, it is government basic responsibility to provide security.For effective security to prevail there should exist a working relationship between governments, Non-Governmental Organizations (NGOs) and Community Based Organizations(CBOs) at internal and local levels, professional groups/bodies, individuals and private citizens, religious/social groups, communication/media, community vigilante, etc. This is to say that security due to its widening nature nowadays is not government business alonebut a corporate business of all.

It is worthy of note that security of one level (government alone) cannot be achieved in isolation of other levels or referent objects or sphere. There must be a correlation or relationship between governments (federal, state, local governments, CBOs, NGOs, professional bodies, individual's citizens, religious groups, traditional institutions, media, etc.) in internal security management. Thus, from the point of view of our model, security for the individual gives room for the security of the nation.State and countries of the world must work co-operatively in the international environment through state and non-state actors to achieve collective security for enhanced global peace.

\section{Conclusion:}

Though the military, Para-military, non-state actors and private security outfits in the Nigerian state have had relative successes in comparison with other African nations, the current overwhelming security threats seem to have revealed its weaknesses which can be traced to the following: 
- $\quad$ Obsolete defense strategy and security equipments.

- Corruption and poor motivation of the Nigerian security and law enforcement personnel.

- Porous Nigerian borders.

- Influx of illegal weapons due to uncontrolled border access.

- Influx of aliens, particularly through the Northern borders of the Nigerian state.

- Lack of new technological facilities for fighting crimes and criminal activities in the Nigerian state.

- Lack of continuous training of security personnel and worse still, Nigerian police personnel whose statutory mandate have failed in the face of current security challenges in Nigeria.

- The current Boko Haram insurgence and continued terrorism have also shown the obsolete equipments of the Nigerian military forces who are now elicit the assistance of the US and European Countries to help fight BokoHaram insurgents in Nigeria, the giant of Africa.

\section{The Way Forward:}

- The way forward arising from this paper is the total over-haul of the entire Nigerian security, intelligence and defense forces by way of recruiting younger graduates with better educational background, particularly, in the Nigerian police.

- There should be deliberate efforts to train, re-train, motivate and properly fund Nigerian security and Paramilitary personnel to cope with security challenges that are contemporary in nature.

- Though, it is the statutory responsibility of the Nigerian Government to provide security for lives and assets of Nigerians, it is imperative that individuals, communities and other non-governmental actors should contribute in maintaining peace, order in the society and collectively help in corporate security in the homes, community and the nation at large.

- The Nigerian state (government) as a way forward must not shy away from her statutory and constitutional role by ensuring proper funding of the nation's security agencies to make them combat ready by adopting holistic approach to security as without security, no meaningful progress can be made in any nation.

- Similarly, it is advised that the militarization policy of the Niger-Delta region is counter-productive and tends to drive the region into war of attention between the federal military forces and the militant youths with attendant security consequences in the region. The idea should be dropped forthwith. In the alternative, a multi-track approach that emphasizes the provision of security as a collective responsibility between government, people / individuals, public and private organizations as well as trans-national NGOs and CBOs as security provision now follows multi-dimensional approach. This is strongly related to the three levels security model of Barry Buzan (1983). The adoption of multi-dimensional security management in the Niger-Delta is necessitatedby the widening nature of security nowadays.

- The Nigerian state should prevail on the MNCs operating in the region to consider the employment of indigenes of the oil-bearing communities so that they will see themselves as stakeholders in the oil industry.

- The Nigerian state and the oil companies should provide the needed infrastructural facilities in the NigerDelta to stem protest and agitations.

\section{References}

[1]. Achebe, C. (1983). The Trouble with Nigeria. Forth Dimension Publishers, Nigeria.

[2]. Agi, A. (2003). An Approach to the Study of Organization of Government. Pigasiann and Grace International Publishers, Calabar and Okuku - Yala, Nigeria.

[3]. Agi, S. (2003). An Approach to the Study of Organization of Government. Pigasiann and Grace International Publishers, Calabar and Okuku - Yala, Nigeria.

[4]. Aja, A. (1999). Policy and Strategic Studies: Unchartered Waters of War and Peace in International Relations. Willy Rose and Appleesed Publishing Company.

[5]. Akpan, O. (2012). War and Conflict without Weapons: Tactics and Strategies of Scorching the Phenomenon of Boko Haram in Nigeria, London, Adomi and Banny.

[6]. Appadorai, A. (1982). Substance of Politics.Oxford University Press, Delhi.

[7]. Art, R. (2001). Security in the Oxford Companion to Politics of the World. Oxford University Press.

[8]. Bennis, A. (2008). Intelligence and National Security. A Brief Historical Perspective in Ayad Nabil Edition. The Impact of Technology on Intelligence and Security. London University of West Minister Press.

[9]. Buzan, B. (1983). People, States and Fear: The National Security Problem in International Relations, Wheatsheaf Books Ltd, Great Britain.

[10]. Buzan, B. (1991). New Patterns of Global Security in the $21^{\text {st }}$ Century, International Affairs, Volume 57, No. 3 pp. $431-451$.

[11]. Collins, A. (2007). Contemporary Security Studies. Oxford University Press.

[12]. Ekpe, A. (2007). State and Economy: An Introduction Essay. Mac grace Academic Resources Publishers, Uyo.

[13]. Eminue, O. (2004:3). Conflict Resolution and management in Nigeria: A Focus on Community Conflicts, A Paper Presented at a Seminar Organized by Elf Petroleum Nigeria Ltd. For Heads of Councils, Chiefs, Women and Community Leaders from the Coastal Communities/Local Government Areas of Akwa Ibom State at Governpr's Office Annex, Wellington Bassey Way, Uyo on Tuesday $19^{\text {th }}$ November, 2004.

[14]. Gana, A and Omelle, Y. (2005). Military and Developmental Dimensions in Conception of Security.Rus Multimedia.

[15]. Global News Trend, June 7, 2010. 
[16]. Ikelegbe, A. (2001). "Civil Society, Oil and Conflict in the Niger-Delta region of Nigeria: Ramifications of Civil Society for a regional Resource Struggle”. Benin City: Department of Political Science \& Public Administration, University of Benin, Nigeria.

[17]. Johari, J. (2005). Contemporary Political Theory, New Dimensions, Basic Concepts and Trends.Sterling Publishers Ltd, New Delhi.

[18]. Johari, J. (2005). Contemporary Political Theory, New Dimensions; Basic Concepts and Major Trends. Sterling Publishers Ltd. New Delhi, India.

[19]. Magstadt, M. (2006). Understanding politics, Ideas, Institutions and Issues. Thomas Wadsworth, USA.

[20]. Nnoli, O. (2006). Security as Protection of Cherished Core Values of Citizens. Forth Dimensions Publication, Enugu, Nigeria.

[21]. Oduneye, O. (2008). Towards Public-Private Partnership in Enhancing Nigeria's National Security Challenges and Prospect. (Unpublished monograph of Senior Executive Course 30) NIPSS, Kuru, Jos.

[22]. Oshita, O. (2001). Philosophy, Education and Environment: The Dialectic of Knowledge. Calabar. University of Calabar Press.

[23]. Phenson, U. (2014). Government and the Management of Security Challenges in Nigeria: A Case of Akwa Ibom State (1999-2011). (Unpublished Ph.D Thesis) University of Uyo, Uyo, Akwa Ibom State, Nigeria.

[24]. The 1999 Constitution of the Federal Republic of Nigeria.

[25]. Umoh, B. (1990). 1988 Civil Service Reforms. Uyo: Seminar Paper Organized by Oduduma School of Management Studies.

[26]. The 1999 Constitution of the Federal Republic of Nigeria, Nigeria.

[27]. Ekpo, A. (2001). Resource Control: Contextual Imperatives and Implications for Nigeria. Lecture Paper Presented during the Obong Sampson UdoEtuk's 2001 Annual Lecture/Award Ceremonies, Uyo, Nigeria.

[28]. Wilson, D. (2006). Politics of Oil and Economics of Oil Politics. A Paper Presented in a Peace Submit Organized by the Akwa Ibom State Oil Producing Community Development Network (AKIPON) Held at Women Development Centre, IBB Way, Uyo, Nigeria.

[29]. Wiwa, K. (1994). Ogoni Movement of Truth. Port Harcourt: Saro International Publishers.

[30]. Global News Trend, June, $7^{\text {th }} 2010$. 